\title{
Groundwater hydrochemistry and isotope geochemistry in the Turpan Basin, northwestern China
}

\author{
Lu CHEN ${ }^{1 *}$, GuangCai WANG ${ }^{1}$, FuSheng $\mathrm{HU}^{1}$, YaJun WANG ${ }^{1}$, Liang LIU $^{2}$ \\ ${ }^{1}$ School of Water Resources and Environment, China University of Geosciences, Beijing 100083, China; \\ ${ }^{2}$ The First Brigade of Hydrogeology, Xinjiang Bureau of Geology and Minerals, Urumqi 830002, China
}

\begin{abstract}
The Turpan Basin is located in the arid zone of northwestern China and is a typical closed inland basin surrounded by high mountains. It is one of the most arid regions in the world and, as a result, the groundwater in this area is very important for both domestic and agricultural uses. In the present study, the relationships of major elements $\left(\mathrm{K}^{+}, \mathrm{Na}^{+}, \mathrm{Ca}^{2+}, \mathrm{Mg}^{2+}, \mathrm{HCO}_{3}{ }^{-}, \mathrm{SO}_{4}{ }^{2-}\right.$ and $\left.\mathrm{Cl}^{-}\right)$and environmental isotopes $\left(\delta^{18} \mathrm{O}, \delta^{2} \mathrm{H}\right.$ and $\left.\mathrm{T}\right)$ in groundwater were analyzed to investigate the evolution of the regional hydrochemistry within the Turpan Basin. The hydrochemistry results demonstrate that groundwater with high total dissolved solids (TDS) concentration is dominated by sodium chloride $(\mathrm{Na}-\mathrm{Cl})$ and sodium sulfate $\left(\mathrm{Na}-\mathrm{SO}_{4}\right)$ type water, whereas that with low TDS concentration (typically from near mountain areas) is dominated by calcium bicarbonate $\left(\mathrm{Ca}-\mathrm{HCO}_{3}\right)$ type water. The evolution of groundwater hydrochemistry within the Turpan Basin is a result of calcium carbonate precipitation, evaporation concentration, cation exchange and dissolution of evaporites (i.e. halite, mirabilite and gypsum). Furthermore, evaporite dissolution associated with irrigation practice plays a key role in the groundwater salinization, especially in the central part of the basin. Environmental isotopes reveal that the groundwater is recharged by precipitation in the mountain areas and fast vertical infiltration of irrigation return flow. In the southern sub-basin the shallow groundwater and the deep groundwater is separated at a depth of about $40 \mathrm{~m}$, with substantial differences in terms of hydrochemical and isotopic characteristics. The results are useful for decision making related to sustainable water resource utilization in the Turpan Basin and other regions in northwestern China.
\end{abstract}

Keywords: hydrochemistry; environmental isotopes; groundwater salinization; evaporite dissolution; Turpan Basin

Citation: Lu CHEN, GuangCai WANG, FuSheng HU, YaJun WANG, Liang LIU. 2014. Groundwater hydrochemistry and isotope geochemistry in the Turpan Basin, northwestern China. Journal of Arid Land, 6(4): 378-388. doi: 10.1007/s40333-013-0249-9

In northwestern China, one of the most water-stressed regions in the world, groundwater is a primary water resource for both domestic and agricultural uses $(\mathrm{Qu}$, 1991). However, owing to human population growth and climate change, the use of groundwater resources has increased dramatically in recent decades, and this intense exploitation of groundwater has resulted in its continuous salinization. Accordingly, groundwater salinization in this region has become a major challenge for sustainable social and economic development (Shi and Zhang, 1995). Thus, it is urgent to understand the processes controlling the salinization of groundwater in northwestern China to ensure effective groundwater management and conservation (Zhou et

\section{al., 2005).}

In inland basins, the salinity of groundwater can generally be attributed to the dissolution of secondary minerals in sedimentary formations (Howard and Lioyd, 1983), evapotranspiration (Fass et al., 2007), irrigation return flow, anthropogenic contamination, or a combination of these processes (Ghabayen et al., 2006).

The Turpan Basin is rich in mineral resources and most hydrogeochemical studies have been performed for the purpose of mineral resources exploitation. However, several studies have provided important information regarding groundwater chemistry in the basin. Chen (1959) demonstrated that the TDS

*Corresponding author: Lu CHEN (E-mail: chenlu_218@aliyun.com)

Received 2013-03-25; revised 2013-07-21; accepted 2013-09-05

(C) Xinjiang Institute of Ecology and Geography, Chinese Academy of Sciences, Science Press and Springer-Verlag Berlin Heidelberg 2014 
concentration of groundwater increases from the edge towards the center of the Turpan Basin. It has also been established that TDS varies considerably between the shallow and deep groundwater in the southern sub-basin, where a critical boundary layer occurs at a depth of about $30 \mathrm{~m}$. Li (1995) has examined the hydrogeochemistry and isotopes in the Shanshan area, but only preliminary results are available due to data limitations. Zhou and Zhang (2005) has shown that the potentially exploitable groundwater resources in the Turpan Basin is only $0.8 \times 10^{8} \mathrm{~m}^{3}$. Recent developments have resulted in a decline in both the quantity and quality of the groundwater resources. However, very little research has focused on evaluating the hydrochemical and physical processes in the basin through analysis of hydrochemical and isotopic data, including the impact of irrigation on groundwater. To address this, the present study characterizes groundwater flow and analyzes major elements and environmental isotopes in the groundwater to provide information about the factors controlling groundwater salinization in the basin.

\section{Study area}

The Turpan Basin is confined by the Bogeda Mountain to the west and north, the Queletage Mountain to the south, and low hills and the Kumtag Desert to the east (where it borders the Hami Basin) (Fig. 1). The Flame and Salt Mountains (500-850 m asl) are located in the middle of the Turpan Basin, dividing the basin into three mountainous regions with two intervening sub-basins. Ayding Lake (-154 $\mathrm{m}$ asl), the lowest point in China, is located in the southern sub-basin of the study area. Owing to its location, topography and terrain, the Turpan Basin experiences a unique temperate arid desert climate: it is dry, hot and windy.

Statistical data obtained from three weather stations (Turpan, Tockson and Shanshan) demonstrate that the minimum and maximum average monthly temperatures in the region were $-15.9^{\circ} \mathrm{C}$ (in January) and $34.1^{\circ} \mathrm{C}$ (in July), respectively. The Turpan Basin is one of China's most arid regions and has very little precipitation. From north to south (with declining altitudes), days of precipitation decrease and the average annual precipitation in the basin is only $16.6 \mathrm{~mm}$ (with a relatively larger range of $150-600 \mathrm{~mm}$ in the northern mountain areas). Average Annual evaporation is about 2,845 mm (Halik et al., 2009).

The Turpan Basin contains a wide spread of Quaternary sediments, except in the mountain areas. From the edge to the center of the basin, Quaternary sediments occur as ring belts. These deposits can be divided into several depositional facies: alluvial, lacustrine, marsh and eolian. The lithologies typically

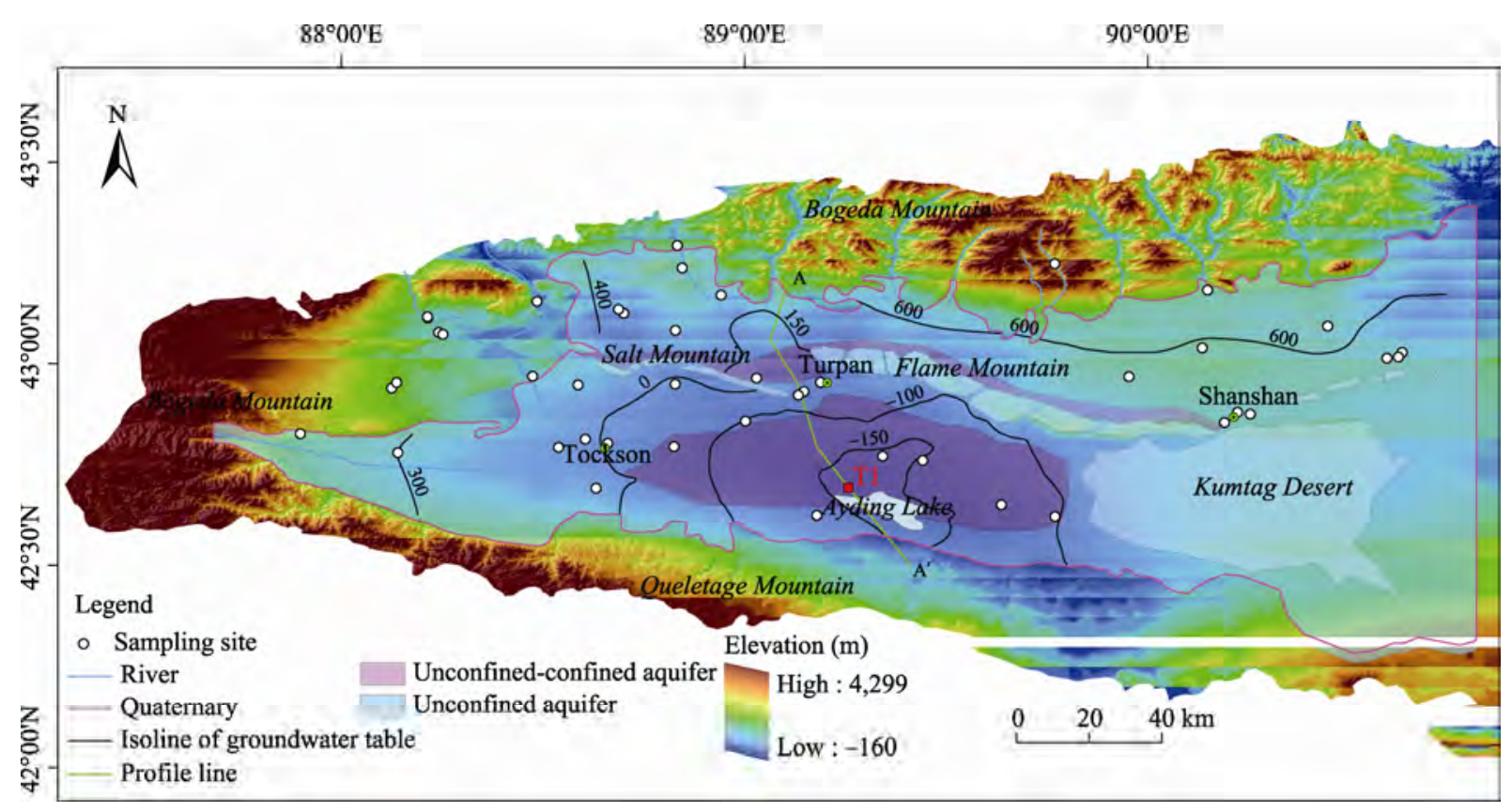

Fig. 1 Study area and sampling sites 
include gravel, sandy gravel, sandy clay and clay. These sediments are typically composed of variable amounts of quartz, illite-smectite, feldspar and calcite. Saline soils are very common throughout the Turpan Basin owing to intensive evaporation and high groundwater tables. Evaporites including halite $(\mathrm{NaCl})$, mirabilite $\left(\mathrm{Na}_{2} \mathrm{SO}_{4} \cdot 10 \mathrm{H}_{2} \mathrm{O}\right)$ and gypsum $\left(\mathrm{CaSO}_{4} \cdot 2 \mathrm{H}_{2} \mathrm{O}\right)$ have been found to occur as ephemeral accumulations on the land surface, particularly in the center of the basin (Wang and Wu, 2003). The northern sub-basin is characterized by Quaternary gravel and sand with thicknesses varying from tens of meters to several thousand meters and groundwater depths of 30-300 m. A single unconfined aquifer is formed in this area due to the absence of clay layers. In contrast, many clay layers can be found along the northern side of the Flaming and Salt mountains, resulting in the formation of several confined aquifers. The thickness of Quaternary sediments in the southern sub-basin varies from tens of meters to hundreds of meters. The clay content of the Quaternary sediments is particularly high close to Ayding Lake, resulting in the formation of a confined aquifer around the lake. The bottom of the aquifer is defined by Tertiary bed rock.



Fig. 2 A hydrogeological section along line $A-A^{\prime}$ in the Turpan Basin (1, clay; 2, silt; 3, sandy soil; 4, gravel; 5, fault; 6 , groundwater table; 7 , vertical recharge; 8 , evaporation; 9 , lateral recharge; 10 , bedrock)

The groundwater flow system of the Turpan Basin is constrained by the terrain and can be divided into three fundamental flow systems: Turpan to Ayding Lake, Shanshan to Ayding Lake and Tockson to Ayding Lake. The average annual precipitation in the
Turpan Basin is only $16.6 \mathrm{~mm}$, yet the average annual evaporation is $2,845 \mathrm{~mm}$; thus, it is clear that groundwater cannot be recharged effectively by precipitation falling within the basin. Rather, groundwater recharge is achieved through precipitation and snow melt in the surrounding mountain areas. The water in the Turpan Basin flows along the following pathway: from the mountain areas to the piedmont belt of Gobi, to the Flaming Mountain overflow belt, to the fine soil plain, and finally to Ayding Lake (Fig. 2). This process is an important feature of the formation and distribution of water resources in this inland basin (Li et al., 1995).

\section{Methods}

A total of 45 water samples were collected for hydrochemical analysis in June 2011. Sampling locations were determined using a handheld global positioning system (GPS) (Kansas, USA). The following parameters were analyzed in the field or laboratory: TDS, $\mathrm{pH}$, $\mathrm{Ca}^{2+}, \mathrm{Mg}^{2+}, \mathrm{Na}^{+}, \mathrm{K}^{+}, \mathrm{SO}_{4}{ }^{2-}, \mathrm{HCO}_{3}{ }^{-}$and $\mathrm{Cl}^{-}$. All water samples were filtered through $0.45-\mu \mathrm{m}$ membranes on site and placed in high-density polypropylene bottles that had been washed with $1 \% \mathrm{HNO}_{3}$. Unstable hydrochemical parameters including groundwater temperature and $\mathrm{pH}$ were measured in situ using a portable $\mathrm{pH}$ meter and combined temperature meter. Concentrations of major anions $\left(\mathrm{Cl}^{-}, \mathrm{NO}_{3}{ }^{-}\right.$and $\left.\mathrm{SO}_{4}{ }^{2-}\right)$ and cations $\left(\mathrm{Na}^{+}, \mathrm{K}^{+}, \mathrm{Ca}^{2+}\right.$ and $\left.\mathrm{Mg}^{2+}\right)$ were analyzed in the laboratory of the School of Water Resources and Environment, China University of Geosciences in Beijing. Sulfate $\left(\mathrm{SO}_{4}{ }^{2-}\right)$ measuring of the water samples was conducted using a spectrophotometer and carbonate $\left(\mathrm{CO}_{3}{ }^{-}\right)$. Bicarbonate $\left(\mathrm{HCO}_{3}{ }^{-}\right)$, calcium $\left(\mathrm{Ca}^{2+}\right)$ and magnesium $\left(\mathrm{Mg}^{2+}\right)$ contents were determined by volumetric methods. Sodium $\left(\mathrm{Na}^{+}\right)$and potassium $\left(\mathrm{K}^{+}\right)$ contents were determined using a flame photometer. The analytical precision reported by the laboratory was better than $5 \%$ for all hydrochemical parameters.

Samples for isotopic analysis were collected in July 2012. A total of 57 samples were collected in glass bottles with gas-tight caps and used for analysis of $\delta^{18} \mathrm{O}, \delta \mathrm{D}$ and $\mathrm{T}$ at the State Key Laboratory of Geological Processes and Mineral Resources, China University of Geosciences in Beijing. Stable isotopes $\left(\delta^{18} \mathrm{O}\right.$ and $\left.\delta \mathrm{D}\right)$ were measured by a VG Micromass $602 \mathrm{C}$ isotope ratio mass spectrometer relative to 
international standards calibrated with respect to V-SMOW (Vienna Standard Mean Ocean Water) and were reported in conventional $\delta(\%)$ notation. Analytical precision was $\pm 0.1 \%$ for $\delta^{18} \mathrm{O}$ and $\pm 1 \%$ for $\delta \mathrm{D}$. Samples for $\mathrm{T}$ analysis were electrolytically enriched and analyzed using a Quantulus 1220 liquid scintillation beta spectrometer. Results were reported in $\mathrm{T}$ units
(TU) with a typical error of \pm 1 TU (Wang, 2002).

\section{Results}

\subsection{Hydrochemical characteristics}

Table 1 shows the results of analysis of the surface and groundwater samples used in the present study.

Table 1 Results of chemical analysis for surface and groundwater samples from the Turpan Basin

\begin{tabular}{|c|c|c|c|c|c|c|c|c|c|c|c|c|c|}
\hline \multirow{2}{*}{ Sample } & \multicolumn{2}{|c|}{ Location } & \multirow{2}{*}{$\mathrm{pH}$} & \multirow{2}{*}{$\begin{array}{l}\text { Depth } \\
\text { (m) }\end{array}$} & $\mathrm{K}^{+}$ & $\mathrm{Na}^{+}$ & $\mathrm{Ca}^{2+}$ & $\mathrm{Mg}^{2+}$ & $\mathrm{Cl}^{-}$ & $\mathrm{SO}_{4}{ }^{2-}$ & $\mathrm{HCO}_{3}{ }^{-}$ & TDS & \multirow{2}{*}{ Water type } \\
\hline & Latitude & Longitude & & & \multicolumn{8}{|c|}{$(\mathrm{mg} / \mathrm{L})$} & \\
\hline R4 & $88^{\circ} 50^{\prime} 00^{\prime \prime}$ & $43^{\circ} 17^{\prime} 37^{\prime \prime}$ & 7.87 & 0 & 0.8 & 9.8 & 52.1 & 7.3 & 7.1 & 67.2 & 122.0 & 223.3 & River \\
\hline R3 & $88^{\circ} 28^{\prime} 28^{\prime \prime}$ & $42^{\circ} 58^{\prime} 08^{\prime \prime}$ & 7.73 & 0 & 1.9 & 59.4 & 76.2 & 17.0 & 60.3 & 172.9 & 170.9 & 473.2 & River \\
\hline $\mathrm{R} 2$ & $88^{\circ} 29^{\prime} 08^{\prime \prime}$ & $43^{\circ} 09^{\prime} 18^{\prime \prime}$ & 7.88 & 0 & 1.2 & 23.7 & 62.1 & 17.0 & 20.6 & 105.7 & 183.1 & 348.2 & River \\
\hline R7 & $90^{\circ} 08^{\prime} 55^{\prime \prime}$ & $43^{\circ} 10^{\prime} 58^{\prime \prime}$ & 7.57 & 0 & 1.7 & 17.4 & 52.1 & 12.2 & 21.3 & 57.6 & 152.6 & 238.6 & River \\
\hline R6 & $89^{\circ} 46^{\prime} 10^{\prime \prime}$ & $43^{\circ} 14^{\prime} 54^{\prime \prime}$ & 7.83 & 0 & 1.7 & 18.4 & 60.1 & 17.0 & 14.2 & 48.0 & 213.6 & 266.2 & River \\
\hline R5 & $88^{\circ} 56^{\prime} 30^{\prime \prime}$ & $43^{\circ} 10^{\prime} 15^{\prime \prime}$ & 7.79 & 0 & 1.1 & 26.7 & 64.1 & 17.0 & 46.1 & 115.3 & 152.6 & 346.6 & River \\
\hline $\mathrm{J} 22$ & $90^{\circ} 37^{\prime} 52^{\prime \prime}$ & $43^{\circ} 01^{\prime} 43^{\prime \prime}$ & 7.72 & 32 & 2.7 & 205.1 & 68.1 & 24.3 & 198.5 & 259.4 & 146.4 & 831.3 & Unconfined \\
\hline $\mathrm{J} 23$ & $90^{\circ} 37^{\prime} 18^{\prime \prime}$ & $43^{\circ} 01^{\prime} 00^{\prime \prime}$ & 7.66 & 29 & 2.1 & 152.7 & 56.1 & 24.3 & 120.5 & 230.5 & 183.1 & 677.8 & Unconfined \\
\hline J3 & $90^{\circ} 15^{\prime} 14^{\prime \prime}$ & $42^{\circ} 52^{\prime} 31^{\prime \prime}$ & 7.62 & 19 & 1.7 & 38.2 & 56.1 & 14.6 & 60.3 & 86.5 & 140.3 & 327.6 & Unconfined \\
\hline J18 & $90^{\circ} 13^{\prime} 22^{\prime \prime}$ & $42^{\circ} 52^{\prime} 47^{\prime \prime}$ & 7.70 & 19 & 2.0 & 31.2 & 56.1 & 19.4 & 49.6 & 67.2 & 164.8 & 307.9 & Unconfined \\
\hline J19 & $90^{\circ} 11^{\prime} 26^{\prime \prime}$ & $42^{\circ} 51^{\prime} 16^{\prime \prime}$ & 7.38 & 7 & 3.6 & 270.6 & 460.9 & 72.9 & 343.9 & 1,364.1 & 170.9 & $2,601.4$ & Unconfined \\
\hline $\mathrm{J} 20$ & $90^{\circ} 35^{\prime} 35^{\prime \prime}$ & $43^{\circ} 00^{\prime} 49^{\prime \prime}$ & 7.35 & 27 & 3.1 & 137.3 & 168.3 & 53.5 & 390.0 & 230.5 & 109.8 & $1,037.6$ & Unconfined \\
\hline $\mathrm{J} 13$ & $90^{\circ} 26^{\prime} 47^{\prime \prime}$ & $43^{\circ} 05^{\prime} 37^{\prime \prime}$ & 7.55 & 310 & 2.3 & 32.3 & 48.1 & 14.6 & 21.3 & 57.6 & 183.1 & 267.8 & Confined \\
\hline $\mathrm{J} 12$ & $89^{\circ} 57^{\prime} 13^{\prime \prime}$ & $42^{\circ} 58^{\prime} 04^{\prime \prime}$ & 7.81 & 83 & 1.0 & 16.7 & 20.0 & 4.9 & 7.1 & 9.6 & 103.7 & 134.4 & Confined \\
\hline J5 & $89^{\circ} 11^{\prime} 19^{\prime \prime}$ & $42^{\circ} 57^{\prime} 14^{\prime \prime}$ & 7.49 & 35 & 2.4 & 132.9 & 192.4 & 43.7 & 390.0 & 249.8 & 97.6 & $1,060.0$ & Unconfined \\
\hline J6 & $89^{\circ} 08^{\prime} 52^{\prime \prime}$ & $42^{\circ} 55^{\prime} 53^{\prime \prime}$ & 7.47 & 20 & 1.1 & 33.7 & 32.1 & 17.0 & 24.8 & 86.5 & 122.0 & 256.2 & Unconfined \\
\hline $\mathrm{J} 7$ & $89^{\circ} 08^{\prime} 01^{\prime \prime}$ & $42^{\circ} 55^{\prime} 20^{\prime \prime}$ & 7.02 & 11 & 1.1 & 38.6 & 32.1 & 9.7 & 21.3 & 76.8 & 128.1 & 243.6 & Unconfined \\
\hline J8 & $89^{\circ} 00^{\prime} 08^{\prime \prime}$ & $42^{\circ} 51^{\prime} 28^{\prime \prime}$ & 7.46 & 7 & 2.6 & 178.5 & 104.2 & 26.7 & 372.2 & 163.3 & 97.6 & 896.3 & Unconfined \\
\hline J9 & $89^{\circ} 01^{\prime} 46^{\prime \prime}$ & $42^{\circ} 57^{\prime} 53^{\prime \prime}$ & 7.55 & 16 & 1.3 & 59.7 & 76.2 & 26.7 & 46.1 & 259.4 & 122.0 & 530.4 & Unconfined \\
\hline $\mathrm{J} 10$ & $89^{\circ} 20^{\prime} 33^{\prime \prime}$ & $42^{\circ} 46^{\prime} 14^{\prime \prime}$ & 7.78 & 10 & 0.7 & 57.2 & 8.0 & 9.7 & 21.3 & 86.5 & 73.2 & 220.0 & Unconfined \\
\hline $\mathrm{J} 1$ & $88^{\circ} 07^{\prime} 31^{\prime \prime}$ & $42^{\circ} 56^{\prime} 22^{\prime \prime}$ & 7.62 & 80 & 1.7 & 187.6 & 52.1 & 14.6 & 92.2 & 249.8 & 250.2 & 723.1 & Confined \\
\hline $\mathrm{J} 2$ & $87^{\circ} 53^{\prime} 54^{\prime \prime}$ & $42^{\circ} 49^{\prime} 35^{\prime \prime}$ & 8.02 & 7 & 3.1 & 45.0 & 70.1 & 27.9 & 58.5 & 129.7 & 213.6 & 456.2 & Unconfined \\
\hline $\mathrm{J} 14$ & $88^{\circ} 32^{\prime} 20^{\prime \prime}$ & $42^{\circ} 47^{\prime} 34^{\prime \prime}$ & 7.65 & 15 & 4.9 & 64.3 & 64.1 & 21.9 & 56.7 & 172.9 & 189.2 & 479.4 & Unconfined \\
\hline $\mathrm{J} 15$ & $88^{\circ} 36^{\prime} 18^{\prime \prime}$ & $42^{\circ} 48^{\prime} 47^{\prime \prime}$ & 7.50 & 13 & 3.9 & 92.4 & 104.2 & 51.0 & 170.2 & 278.6 & 201.4 & 801.0 & Unconfined \\
\hline J16 & $88^{\circ} 39^{\prime} 40^{\prime \prime}$ & $42^{\circ} 48^{\prime} 10^{\prime \prime}$ & 7.40 & 140 & 3.1 & 20.9 & 32.1 & 9.7 & 14.2 & 19.2 & 164.8 & 181.6 & Confined \\
\hline TK10 & $89^{\circ} 10^{\prime} 45^{\prime \prime}$ & $42^{\circ} 37^{\prime} 25^{\prime \prime}$ & 7.74 & 44 & 8.3 & 458.6 & 192.4 & 46.2 & 602.6 & 643.6 & 54.9 & $2,017.0$ & Confined \\
\hline TK11 & $89^{\circ} 26^{\prime} 31^{\prime \prime}$ & $42^{\circ} 45^{\prime} 37^{\prime \prime}$ & 7.94 & 19 & 1.7 & 96.3 & 36.1 & 17.0 & 70.9 & 172.9 & 109.8 & 476.2 & Unconfined \\
\hline TK15 & $89^{\circ} 46^{\prime} 11^{\prime \prime}$ & $42^{\circ} 37^{\prime} 14^{\prime \prime}$ & 7.89 & 15 & 2.1 & 102.9 & 64.1 & 17.0 & 148.9 & 172.9 & 97.6 & 583.7 & Unconfined \\
\hline TK16 & $89^{\circ} 38^{\prime} 14^{\prime \prime}$ & $42^{\circ} 38^{\prime} 59^{\prime \prime}$ & 8.02 & 8 & 1.7 & 93.5 & 40.1 & 9.7 & 70.9 & 134.5 & 109.8 & 430.1 & Unconfined \\
\hline TK17 & $90^{\circ} 08^{\prime} 07^{\prime \prime}$ & $43^{\circ} 02^{\prime} 22^{\prime \prime}$ & 7.98 & 235 & 1.2 & 22.1 & 28.1 & 4.9 & 14.2 & 38.4 & 103.7 & 181.6 & Confined \\
\hline TK2 & $88^{\circ} 08^{\prime} 24^{\prime \prime}$ & $42^{\circ} 46^{\prime} 45^{\prime \prime}$ & 7.93 & 145 & 2.9 & 22.1 & 32.1 & 20.7 & 30.1 & 52.8 & 146.4 & 255.4 & Confined \\
\hline TK4 & $88^{\circ} 35^{\prime} 13^{\prime \prime}$ & $42^{\circ} 56^{\prime} 52^{\prime \prime}$ & 7.63 & 158 & 1.5 & 78.6 & 32.1 & 2.4 & 35.4 & 67.2 & 177.0 & 329.7 & Confined \\
\hline TK5 & $88^{\circ} 37^{\prime} 55^{\prime \prime}$ & $42^{\circ} 41^{\prime} 28^{\prime \prime}$ & 8.18 & 135 & 3.6 & 68.4 & 28.1 & 16.0 & 53.2 & 96.1 & 170.9 & 376.8 & Confined \\
\hline TK6 & $88^{\circ} 50^{\prime} 44^{\prime \prime}$ & $43^{\circ} 14^{\prime} 16^{\prime \prime}$ & 7.78 & 17 & 0.9 & 18.2 & 46.5 & 13.1 & 21.3 & 71.1 & 122.0 & 249.2 & Unconfined \\
\hline TK7 & $88^{\circ} 49^{\prime} 43^{\prime \prime}$ & $43^{\circ} 04^{\prime} 59^{\prime \prime}$ & 8.03 & 300 & 0.7 & 22.4 & 26.1 & 8.5 & 8.9 & 38.4 & 122.0 & 196.2 & Confined \\
\hline TK8 & $88^{\circ} 49^{\prime} 42^{\prime \prime}$ & $42^{\circ} 56^{\prime} 58^{\prime \prime}$ & 8.13 & 105 & 1.6 & 46.3 & 24.0 & 9.7 & 24.8 & 48.0 & 146.4 & 253.5 & Confined \\
\hline TK9 & $88^{\circ} 49^{\prime} 31^{\prime \prime}$ & $42^{\circ} 47^{\prime} 40^{\prime \prime}$ & 8.16 & 150 & 2.7 & 37.3 & 20.0 & 4.9 & 14.2 & 18.8 & 128.1 & 194.4 & Confined \\
\hline S5 & $88^{\circ} 08^{\prime} 13^{\prime \prime}$ & $42^{\circ} 57^{\prime} 12^{\prime \prime}$ & 7.85 & 0 & 1.3 & 126.3 & 24.0 & 7.3 & 53.2 & 128.7 & 195.3 & 438.4 & Spring \\
\hline S6 & $88^{\circ} 42^{\prime} 01^{\prime \prime}$ & $43^{\circ} 07^{\prime} 31^{\prime \prime}$ & 7.78 & 0 & 1.0 & 28.8 & 36.1 & 6.3 & 18.4 & 34.6 & 161.1 & 205.8 & Spring \\
\hline S7 & $88^{\circ} 41^{\prime} 16^{\prime \prime}$ & $43^{\circ} 08^{\prime} 06^{\prime \prime}$ & 7.83 & 0 & 0.9 & 40.5 & 44.9 & 23.8 & 21.3 & 76.8 & 203.8 & 310.1 & Spring \\
\hline $\mathrm{S} 2$ & $88^{\circ} 12^{\prime} 51^{\prime \prime}$ & $43^{\circ} 06^{\prime} 49^{\prime \prime}$ & 7.60 & 0 & 1.6 & 95.3 & 56.1 & 17.0 & 60.3 & 124.9 & 256.3 & 483.4 & Spring \\
\hline $\mathrm{S} 1$ & $88^{\circ} 12^{\prime} 49^{\prime \prime}$ & $43^{\circ} 06^{\prime} 59^{\prime \prime}$ & 7.45 & 0 & 1.9 & 100.3 & 60.1 & 17.0 & 62.4 & 134.5 & 274.6 & 513.5 & Spring \\
\hline S3 & $88^{\circ} 14^{\prime} 31^{\prime \prime}$ & $43^{\circ} 04^{\prime} 40^{\prime \prime}$ & 7.45 & 0 & 1.8 & 113.9 & 60.1 & 17.0 & 70.9 & 144.1 & 311.2 & 563.4 & Spring \\
\hline $\mathrm{S} 4$ & $88^{\circ} 15^{\prime} 08^{\prime \prime}$ & $43^{\circ} 04^{\prime} 23^{\prime \prime}$ & 8.05 & 0 & 2.1 & 120.7 & 64.1 & 17.0 & 70.9 & 153.7 & 317.3 & 587.2 & Spring \\
\hline T1 & $89^{\circ} 15^{\prime} 19^{\prime \prime}$ & $42^{\circ} 41^{\prime} 30^{\prime \prime}$ & 7.56 & 2 & 27.8 & $9,648.1$ & 360.7 & 170.1 & $14,800.4$ & $2,737.7$ & 280.7 & $27,885.2$ & Unconfined \\
\hline
\end{tabular}


The results of statistical analysis of groundwater hydrochemistry indicate that the cations $\mathrm{Na}^{+}$and $\mathrm{Ca}^{2+}$ and anions $\mathrm{SO}_{4}{ }^{2-}$ and $\mathrm{Cl}^{-}$are the dominant components of water in the study area (Table 2). Additionally, the coefficient of variance for $\mathrm{HCO}_{3}{ }^{-}$is high, indicating that the distribution of $\mathrm{HCO}_{3}{ }^{-}$is rather uneven. Sample T1 (TDS=27,885.2 mg/L) was collected close to Ayding Lake (Fig. 1) and has been omitted from the analysis because the TDS content of this sample was anomalously high and affected data presentation. Removal of this sample from the analysis had only a very minor effect on the results for the entire basin.

\subsection{Isotope data}

The environmental isotopic ratios of oxygen $\left(\delta^{18} \mathrm{O}\right)$ and hydrogen $\left(\delta^{2} \mathrm{H}\right)$ are excellent tracers for determining the origin of groundwater and have been used widely to study groundwater recharge and mixing of waters from different sources (Subyani, 2004). Table 3 provides a summary of the isotopic analysis results for all of the water samples collected from the Turpan Basin for the present study. The isotopic compositions of the groundwater samples collected vary from $-11.5 \%$ o to $6.9 \%$ for $\delta^{18} \mathrm{O}$ and from $-85 \%$ o to $7 \%$ for $\delta^{2} \mathrm{H}$.

Table 2 The statistical characteristics of ions in the Turpan Basin

\begin{tabular}{lrrrrr}
\hline \multirow{2}{*}{ Ion } & Average & \multicolumn{1}{c}{ Max. } & Min. & SD. & CV (\%) \\
\cline { 2 - 4 } & \multicolumn{5}{c}{$(\mathrm{mg} / \mathrm{L})$} \\
$\mathrm{K}$ & 2.1 & 8.3 & 0.7 & 1.3 & 157 \\
$\mathrm{Na}$ & 82.8 & 458.6 & 9.8 & 82.8 & 100 \\
$\mathrm{Ca}^{2+}$ & 67.8 & 460.9 & 8.0 & 72.7 & 93 \\
$\mathrm{Mg}^{2+}$ & 19.3 & 72.9 & 2.4 & 14.3 & 135 \\
$\mathrm{Cl}^{-}$ & 92.8 & 602.6 & 7.1 & 129.5 & 72 \\
$\mathrm{SO}_{4}{ }^{2-}$ & 159.0 & $1,364.1$ & 9.6 & 215.0 & 74 \\
$\mathrm{HCO}_{3}{ }^{-}$ & 80.6 & 317.3 & 54.9 & 58.3 & 275 \\
\hline
\end{tabular}

Table 3 Results of isotopic analysis for water samples from the Turpan Basin

\begin{tabular}{|c|c|c|c|c|c|c|c|}
\hline Sample & $\delta \mathrm{D}(\%)$ & $\delta^{18} \mathrm{O}(\%)$ & $\mathrm{T}(\mathrm{TU})$ & Sample & $\delta \mathrm{D}(\%)$ & $\delta^{18} \mathrm{O}(\%$ o $)$ & $\mathrm{T}(\mathrm{TU})$ \\
\hline H1 & -63 & -9.7 & $22.1 \pm 0.9$ & S4 & -61 & -8.9 & - \\
\hline $\mathrm{J} 1$ & -62 & -8.9 & $25.3 \pm 1.0$ & S5 & -70 & -10.3 & $1.0 \pm 0.5$ \\
\hline $\mathrm{J} 10$ & -81 & -10.9 & $21.3 \pm 1.0$ & S6 & -68 & -10.0 & $0.8 \pm 0.4$ \\
\hline $\mathrm{J} 11$ & -71 & -10.0 & $0.8 \pm 0.5$ & S7 & -71 & -10.0 & $0.9 \pm 0.4$ \\
\hline $\mathrm{J} 12$ & -69 & -10.3 & - & S8 & -63 & -9.4 & - \\
\hline $\mathrm{J} 13$ & -74 & -10.5 & $4.5 \pm 0.6$ & T1 & 7 & 6.9 & $20.3 \pm 0.9$ \\
\hline $\mathrm{J} 14$ & -58 & -8.6 & - & TK10 & -66 & -9.2 & $<0.4$ \\
\hline $\mathrm{J} 15$ & -66 & -8.5 & - & TK11up & -67 & -9.9 & $0.9 \pm 0.5$ \\
\hline $\mathrm{J} 16$ & -65 & -8.8 & - & TK11down & -77 & -10.8 & $1.0 \pm 0.4$ \\
\hline J17 & -81 & -11.2 & $1.0 \pm 0.4$ & TK15up & -84 & -11.2 & - \\
\hline J18 & -82 & -10.8 & $23.4 \pm 1.0$ & TK15down & -81 & -11.5 & - \\
\hline J19 & -76 & -10.5 & $8.0 \pm 0.7$ & TK16up & -78 & -10.7 & $0.9 \pm 0.5$ \\
\hline $\mathrm{J} 2$ & -52 & -8.1 & - & TK16down & -81 & -10.7 & $0.9 \pm 0.5$ \\
\hline J20 & -77 & -10.5 & $9.1 \pm 0.7$ & TK17 & -75 & -11.1 & - \\
\hline $\mathrm{J} 21$ & -77 & -10.1 & $25.8 \pm 1.0$ & TK2 & -56 & -8.5 & $0.6 \pm 0.4$ \\
\hline $\mathrm{J} 22$ & -75 & -10.6 & $2.6 \pm 0.6$ & TK4 & -72 & -10.2 & - \\
\hline $\mathrm{J} 23$ & -71 & -10.3 & $3.2 \pm 0.6$ & TK5 & -56 & -8.0 & $1.0 \pm 0.4$ \\
\hline J3 & -85 & -10.9 & $17.1 \pm 0.8$ & TK6 & -65 & -9.6 & - \\
\hline $\mathrm{J} 4$ & -56 & -8.7 & $23.8 \pm 1.0$ & TK7 & -74 & -10.2 & - \\
\hline J5 & -64 & -9.8 & $5.1 \pm 0.5$ & TK8 & -72 & -10.8 & - \\
\hline J6 & -67 & -10.0 & $0.7 \pm 0.4$ & TK9up & -55 & -8.4 & $1.6 \pm 0.5$ \\
\hline $\mathrm{J} 7$ & -72 & -10.0 & $3.2 \pm 0.5$ & TK9down & -55 & -8.7 & $0.9 \pm 0.5$ \\
\hline J8 & -69 & -10.0 & $2.8 \pm 0.5$ & R4 & -58 & -9.4 & - \\
\hline J9 & -64 & -9.8 & $0.9 \pm 0.4$ & R5 & -59 & -9.5 & $26.7 \pm 1.0$ \\
\hline K1 & -60 & -9.0 & - & R6 & -58 & -9.4 & $20.7 \pm 0.8$ \\
\hline $\mathrm{R} 1$ & -64 & -8.9 & - & R7 & -78 & -11.3 & $21.3 \pm 0.9$ \\
\hline $\mathrm{R} 2$ & -67 & -9.1 & - & $\mathrm{S} 1$ & -63 & -9.3 & - \\
\hline R3 & -64 & -9.4 & - & $\mathrm{S} 2$ & -61 & -9.3 & - \\
\hline S3 & -63 & -9.0 & - & & & & \\
\hline
\end{tabular}

Note: "-" indicates not tested. 


\section{Discussion}

\subsection{Hydrochemistry}

The TDS values for groundwater exhibit a clear increase along the flow path from the mountain front recharge areas to the discharge areas in the central part of the basin; accordingly, the highest TDS values tend to occur in the southern sub-basin around Ayding Lake (Fig. 3). Groundwater samples with low TDS values, which typically correspond to mountain front areas, are typically of $\mathrm{Ca}-\mathrm{HCO}_{3}$ and $\mathrm{Ca}-\mathrm{HCO}_{3}-\mathrm{SO}_{4}$ type water. In contrast, groundwater samples with high TDS values, most of which were collected in the center of the basin, are typically of $\mathrm{Na}-\mathrm{Cl}$ and $\mathrm{Na}-\mathrm{SO}_{4}-\mathrm{Cl}$ type water and are characterized by high $\mathrm{Na}^{+}, \mathrm{SO}_{4}{ }^{2-}$, and $\mathrm{Cl}^{-}$concentrations. In fact, the evolution of groundwater from $\mathrm{Ca}^{2+}$ dominated to $\mathrm{Na}^{+}$dominated water can be observed along the groundwater flow path from the mountain front areas to the center of the basin (Fig. 4).

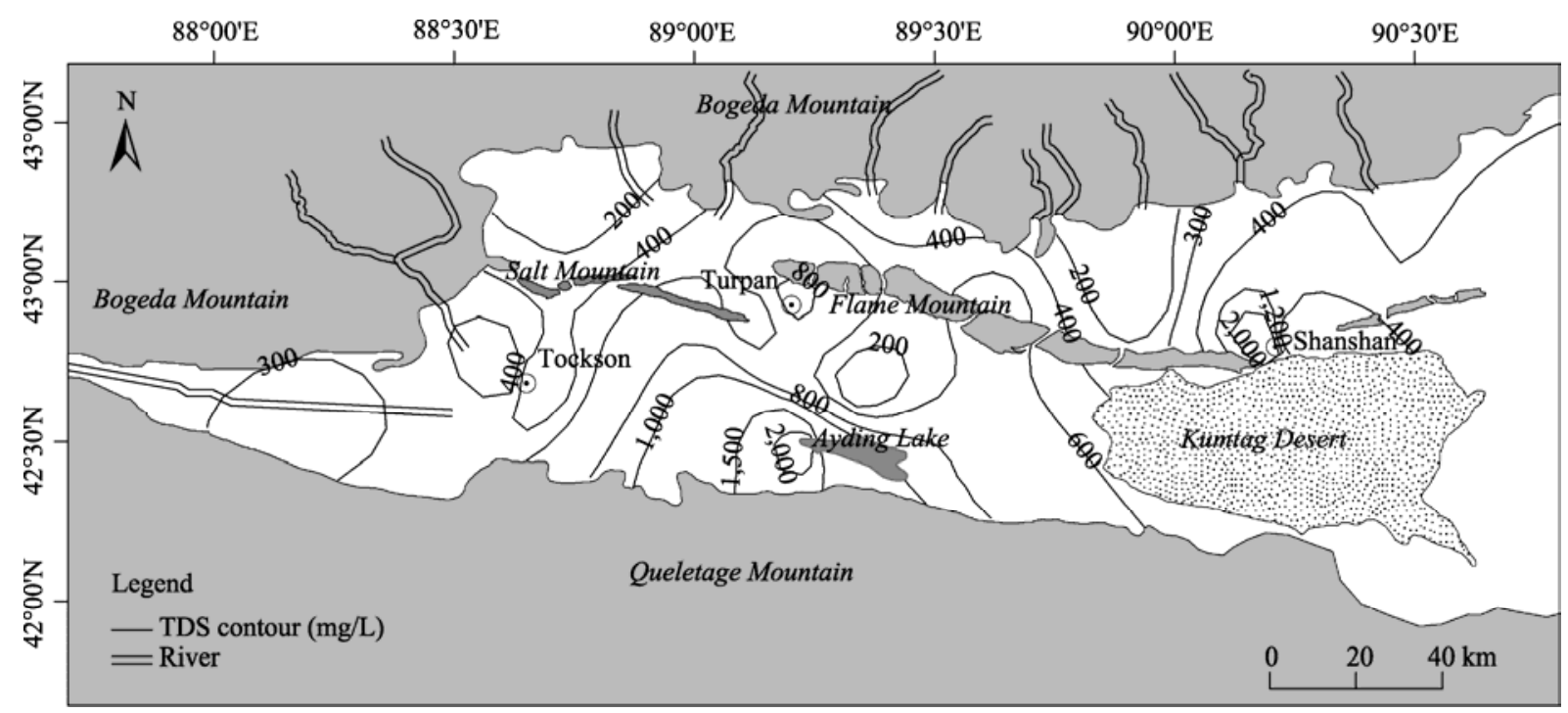

Fig. 3 TDS contours in the Turpan Basin

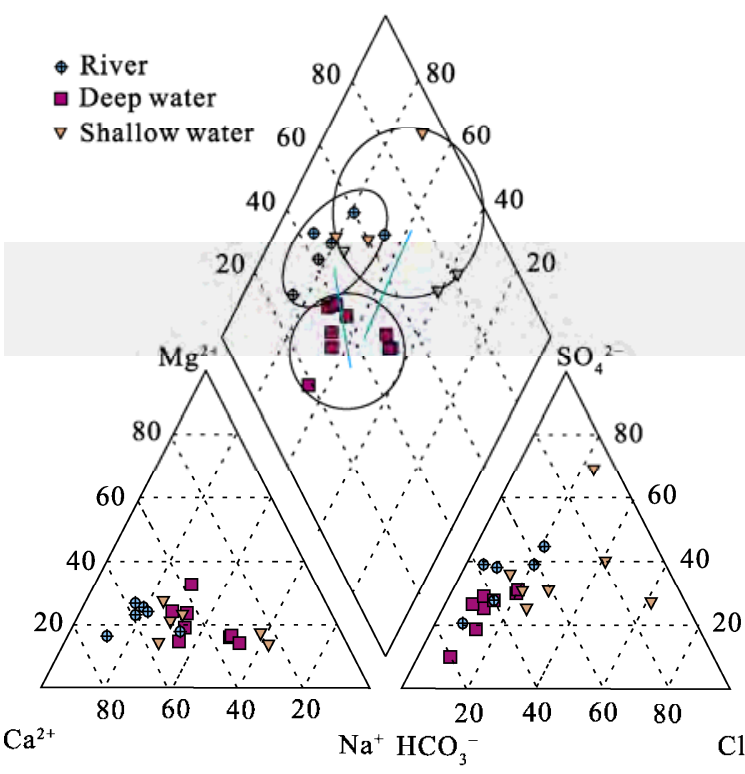

(a)

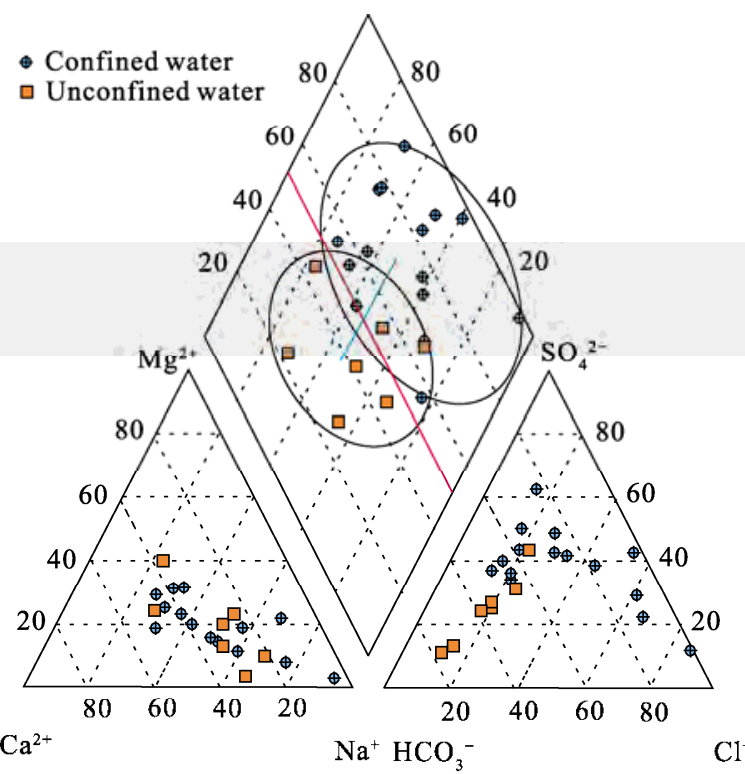

(b)

Fig. 4 Piper diagram of water in the Turpan Basin for water samples in (a) the northern sub-basin and (b) the southern sub-basin 
Figure 5 shows the relationships between major element concentrations and the TDS. The linear relationship indicates that $\mathrm{Na}^{+}, \mathrm{Cl}^{-}, \mathrm{Ca}^{2+}$ and $\mathrm{SO}_{4}{ }^{2-}$ are the primary contributors to groundwater salinity in this region (Fig. 5). These ions are also the major components of evaporites such as halite $(\mathrm{NaCl})$, mirabilite $\left(\mathrm{Na}_{2} \mathrm{SO}_{4} \cdot 10 \mathrm{H}_{2} \mathrm{O}\right)$ and gypsum $\left(\mathrm{CaSO}_{4}\right)$. The observed positive correlations between TDS and $\mathrm{Na}^{+}\left(R^{2}=0.893\right)$, $\mathrm{Cl}^{-}\left(R^{2}=0.895\right), \mathrm{SO}_{4}{ }^{2-}\left(R^{2}=0.930\right)$ and $\mathrm{Ca}^{2+}\left(R^{2}=0.935\right)$ suggest that evaporite dissolution makes a significant contribution to salinization in the basin. Since there is little precipitation in the Turpan Basin, the dissolution of evaporites is probably caused by artificial irrigation. This is also supported by the inverse correlation observed between TDS and water depth (Fig. 6). Although $\mathrm{Mg}^{2+}$ exhibits a strong relationship with TDS, the concentration of $\mathrm{Mg}^{2+}$ is lower than that of all other elements studied; therefore, $\mathrm{Mg}^{2+}$ is not considered as a major element. $\mathrm{HCO}_{3}{ }^{-}$exhibits a negative correlation with TDS values, i.e. as TDS values increase, $\mathrm{HCO}_{3}{ }^{-}$decreases. Moreover, the observation of a significant relationship between $\mathrm{Ca}^{2+}$ and TDS and the positive correlation between $\mathrm{HCO}_{3}{ }^{-}$and TDS suggest that decreases in $\mathrm{HCO}_{3}{ }^{-}$are due primarily to the precipitation of calcium carbonate $\left(\mathrm{CaCO}_{3}\right)$ (Guo and Wang, 2005; Wang, 2002).

Figure 7 shows the correlations between ion pairs, i.e. $\mathrm{Na}^{+}$vs. $\mathrm{SO}_{4}{ }^{2-}, \mathrm{Na}^{+}$vs. $\mathrm{Cl}^{-}, \mathrm{SO}_{4}{ }^{2-}$ vs. $\mathrm{Cl}^{-}$and $\mathrm{Ca}^{2+}$ vs. $\mathrm{SO}_{4}{ }^{2-}$. We can see that sodium increases linearly with chloride. Most groundwater samples have $\mathrm{Na}^{+} / \mathrm{Cl}^{-}$ratios close to 1.0 , suggesting that the dissolution of halite is a significant source of both elements (Appelo and Postma, 2005). However, some groundwater samples have $\mathrm{Na}^{+} / \mathrm{Cl}^{-}$ratios greater than 1.0 and plot above the $\mathrm{Na}^{+} / \mathrm{Cl}^{-}=1$ line (Fig. $7 \mathrm{~b}$ ). $\mathrm{Na}^{+}$and $\mathrm{Cl}^{-}$ enrichment and depletion could be caused by water-sediment interaction. For instance, processes such as sodium-calcium exchange can result in enrichment of $\mathrm{Na}^{+}$over $\mathrm{Cl}^{-}$. The effect of sodium-calcium exchange is confirmed by Fig. 8, which shows the relation between $\mathrm{Na}^{+}-\mathrm{Cl}^{-}$and $\left(\mathrm{HCO}_{3}{ }^{-}+2 \mathrm{SO}_{4}{ }^{2-}\right)-$ $2\left(\mathrm{Ca}^{2+}+\mathrm{Mg}^{2+}\right)$ (García et al., 2001; Carol et al., 2009).

The observed positive correlation between $\mathrm{SO}_{4}{ }^{2-}$ and $\mathrm{Na}^{+}$(Fig. 7a) and $\mathrm{SO}_{4}{ }^{2-}$ and $\mathrm{Ca}^{2+}$ (Fig. 7d) can be attributed to simultaneous dissolution of mirabilite and gypsum. Dissolution of evaporites, including
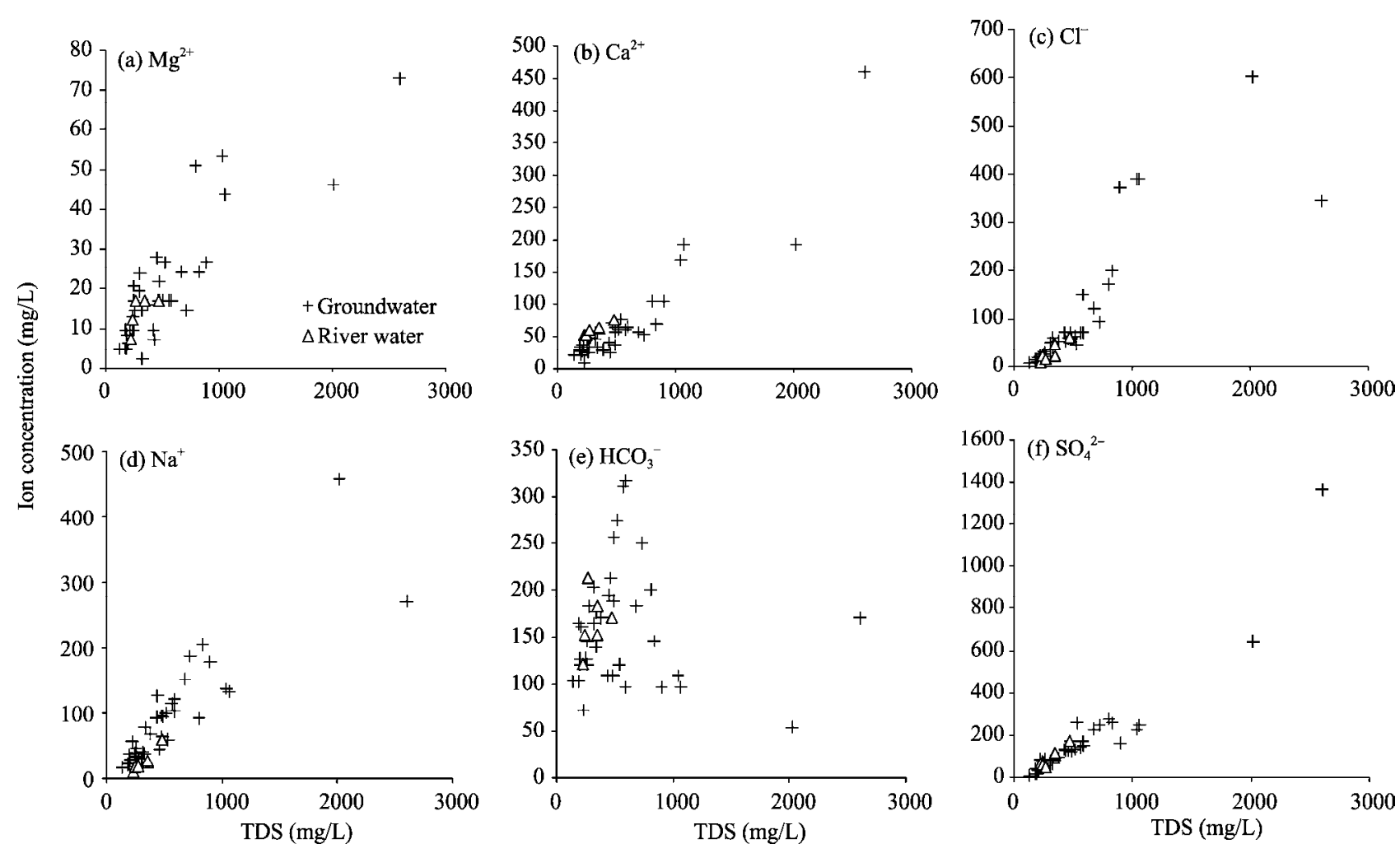

Fig. 5 Relationships between element concentrations and TDS values for surface and groundwater samples from the Turpan Basin 


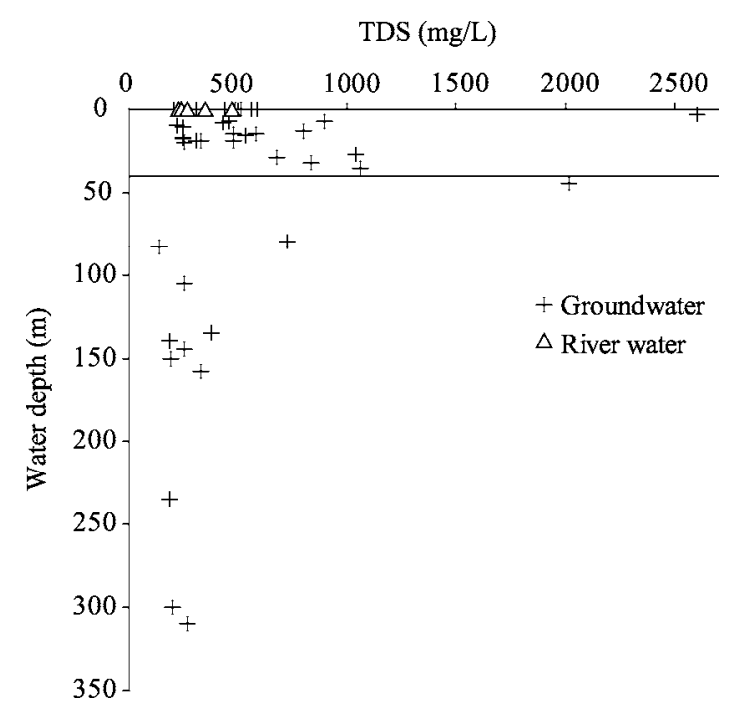

Fig. 6 Scatterplot of TDS vs. water depth in the Turpan Basin
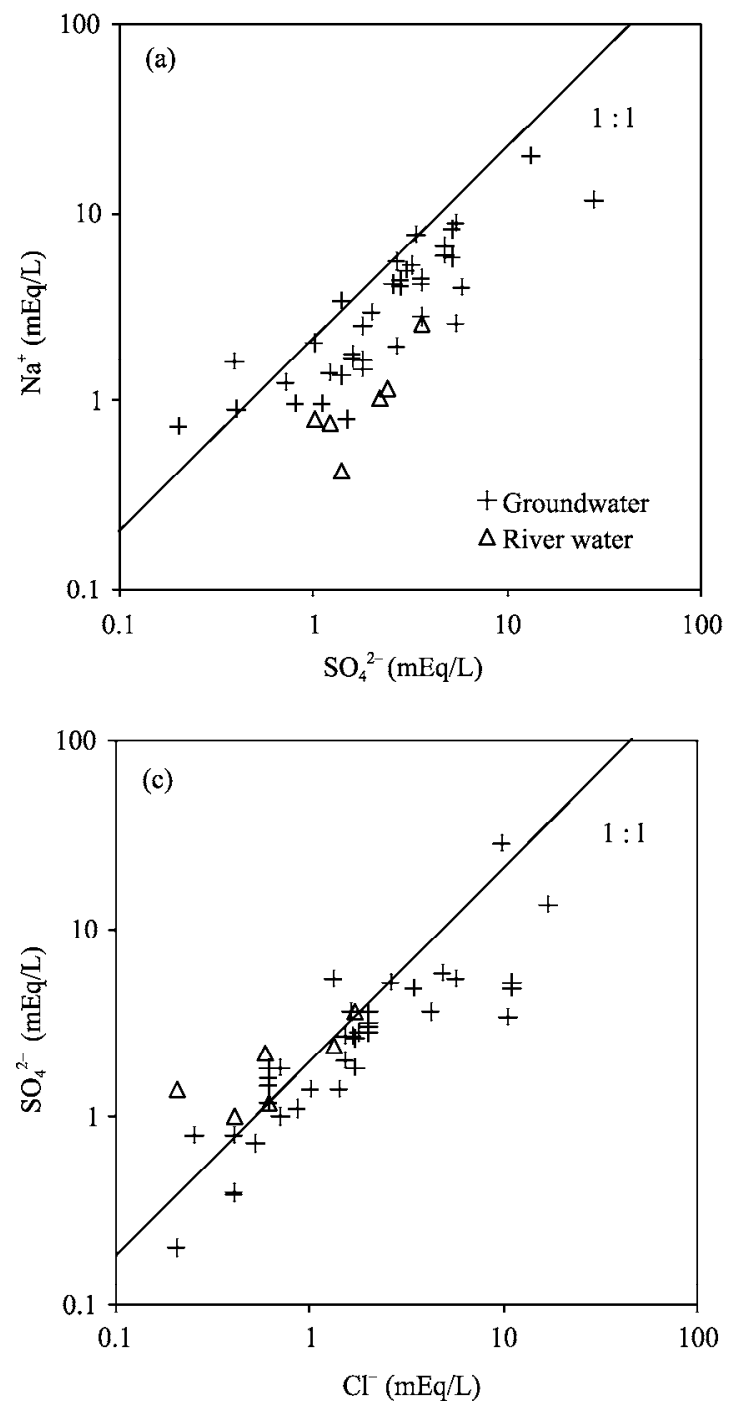

halite, mirabilite and gypsum, can result in the simultaneous increase of $\mathrm{SO}_{4}^{2-}$ and $\mathrm{Cl}^{-}$concentration (Fig. 7c). In the study area, the accumulation of evaporites in the soils is related to strong evapotranspiration due to the slow groundwater flow. Therefore, a greater potential for evapotranspiration can be expected in the unsaturated zone in the central part of the basin (Carol et al., 2009). The intensive evapotranspiration leads to the buildup of evaporites in the unsaturated zone, which is consistent with the occurrence of a wide distribution of saline soils within the Turpan Basin (Han, 2008). The vertical recharge by irrigation return flow in agricultural areas, especially around the central part of the basin where flood irrigation is extensively applied, can cause chemical transport from the surface soil into the groundwater.
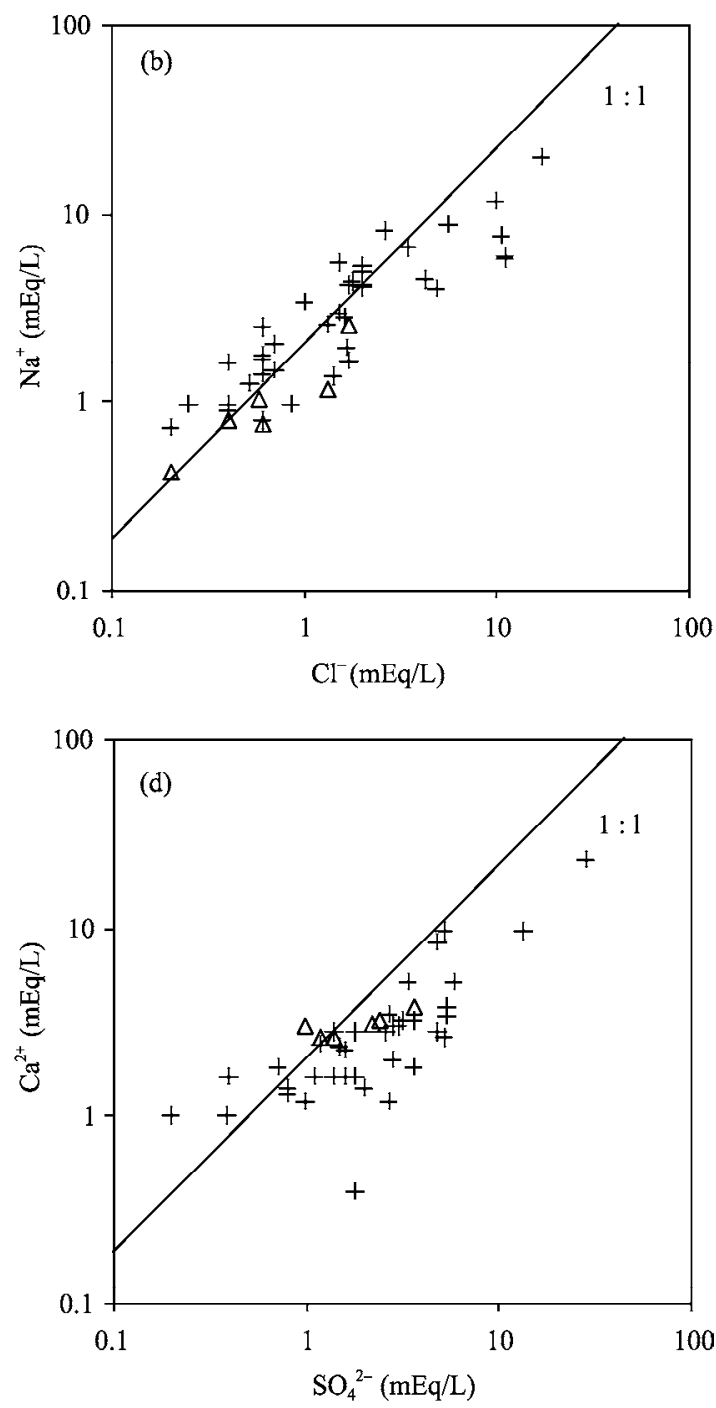

Fig. 7 Scatterplots of (a) $\mathrm{Na}^{+}$vs. $\mathrm{SO}_{4}{ }^{2-}$, (b) $\mathrm{Na}^{+}$vs. $\mathrm{Cl}^{-}$, (c) $\mathrm{SO}_{4}{ }^{2-}$ vs. $\mathrm{Cl}^{-}$and (d) $\mathrm{Ca}^{2+}$ vs. $\mathrm{SO}_{4}{ }^{2-}$ in water samples from the Turpan $\mathrm{Basin}^{-}$ 


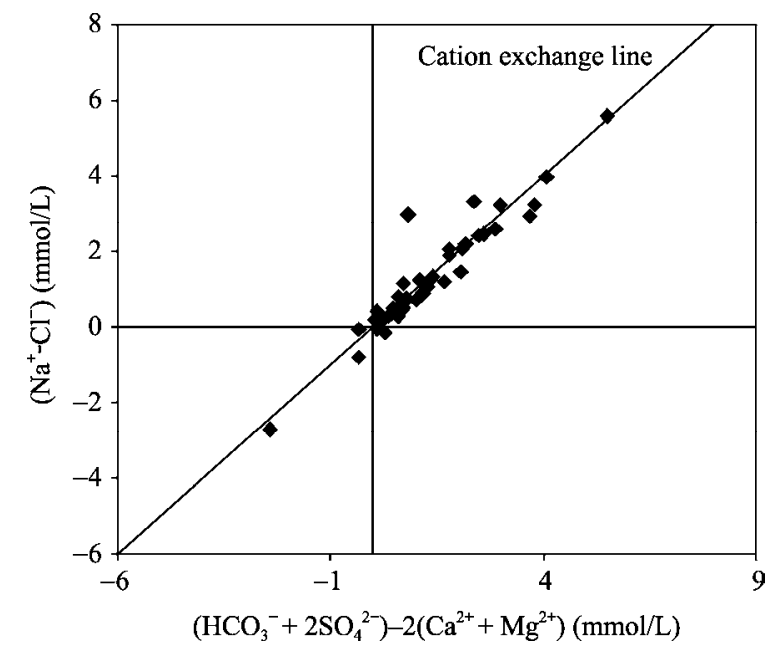

Fig. 8 Relationship between $\left(\mathrm{Na}^{+}-\mathrm{Cl}^{-}\right)$and $\left(\mathrm{HCO}_{3}{ }^{-}+2 \mathrm{SO}_{4}{ }^{2-}\right)-$ $2\left(\mathrm{Ca}^{2+}+\mathrm{Mg}^{2+}\right)$

\subsection{Isotope geochemistry}

In the scatterplot of $\delta^{18} \mathrm{O}$ vs. $\delta^{2} \mathrm{H}$ (Fig. 9), all groundwater samples plot close to the global meteoric water line (GMWL) where $\delta^{2} \mathrm{H}=8 \delta^{18} \mathrm{O}+10$ (Craig, 1961) and the local meteoric water line (LMWL) where $\delta^{2} \mathrm{H}=7.21 \delta^{18} \mathrm{O}+4.5$ (Li et al., 2009). This indicates that the groundwater in this area originates from precipitation. Only one water sample (T1) does not plot close to LMWL and GMWL; this sample was collected close to Ayding Lake. T1 exhibits a TDS value of $27,885.2 \mathrm{mg} / \mathrm{L}$, and the groundwater depth at the sampling location was $2 \mathrm{~m}$. This suggests that evaporation of surface water in the Turpan Basin is very strong but evaporation in deep groundwater is relatively weak.

The plot of $\mathrm{Cl}^{-}$concentrations against $\delta^{18} \mathrm{O}$ values (Fig. 10) can be separated into two zones, in which chloride concentrations (Zone I) increase sharply with little change in $\delta^{18} \mathrm{O}$ values, or $\delta^{18} \mathrm{O}$ values (Zone II) change significantly with only minor changes in $\mathrm{Cl}^{-}$ concentration. In Zone I, the relationship between $\mathrm{Cl}^{-}$ concentration and $\delta^{18} \mathrm{O}$ values reflects the effects of vertical recharge by irrigation return water. During irrigation, low evaporation rates due to fast vertical recharge do not have a significant effect on the $\delta^{18} \mathrm{O}$ values of the groundwater. However, fast vertical recharge by irrigation return water can transport considerable amounts of $\mathrm{Cl}^{-}$to the groundwater owing to the dissolution of evaporites, resulting in sharply increased $\mathrm{Cl}^{-}$concentrations. Therefore, the high $\mathrm{Cl}^{-}$ values in groundwater samples that fall within Zone I can be attributed to irrigation using isotopically depleted groundwater. In contrast, the variability in $\delta^{18} \mathrm{O}$ values may indicate mixing of groundwater along the flow paths from mountain front areas to the center of the basin.

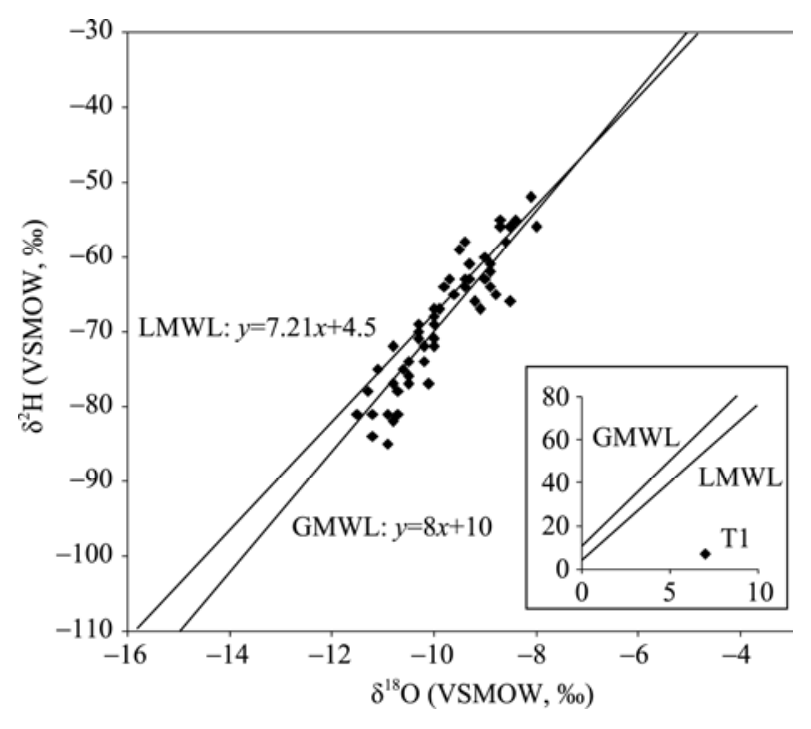

Fig. 9 Scatterplot of $\delta D-\delta^{18} O$ in groundwater and surface water samples from the Turpan Basin

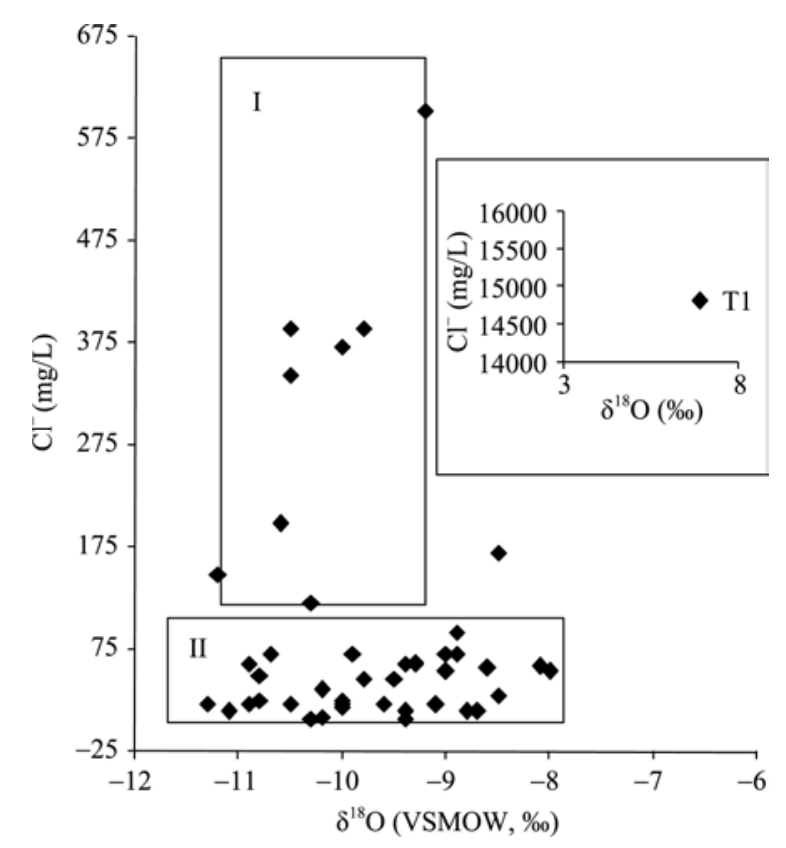

Fig. 10 Scatterplot of $\delta^{18} \mathrm{O}$ vs. $\mathrm{Cl}^{-}$in water samples from the Turpan Basin

The tritium data indicate that the range of tritium concentrations in the Turpan Basin is in agreement with the general rule that tritium concentrations are high in recharge areas but low in runoff and discharge areas (Fig. 11) (IAEA, 2001a, b). Three samples 


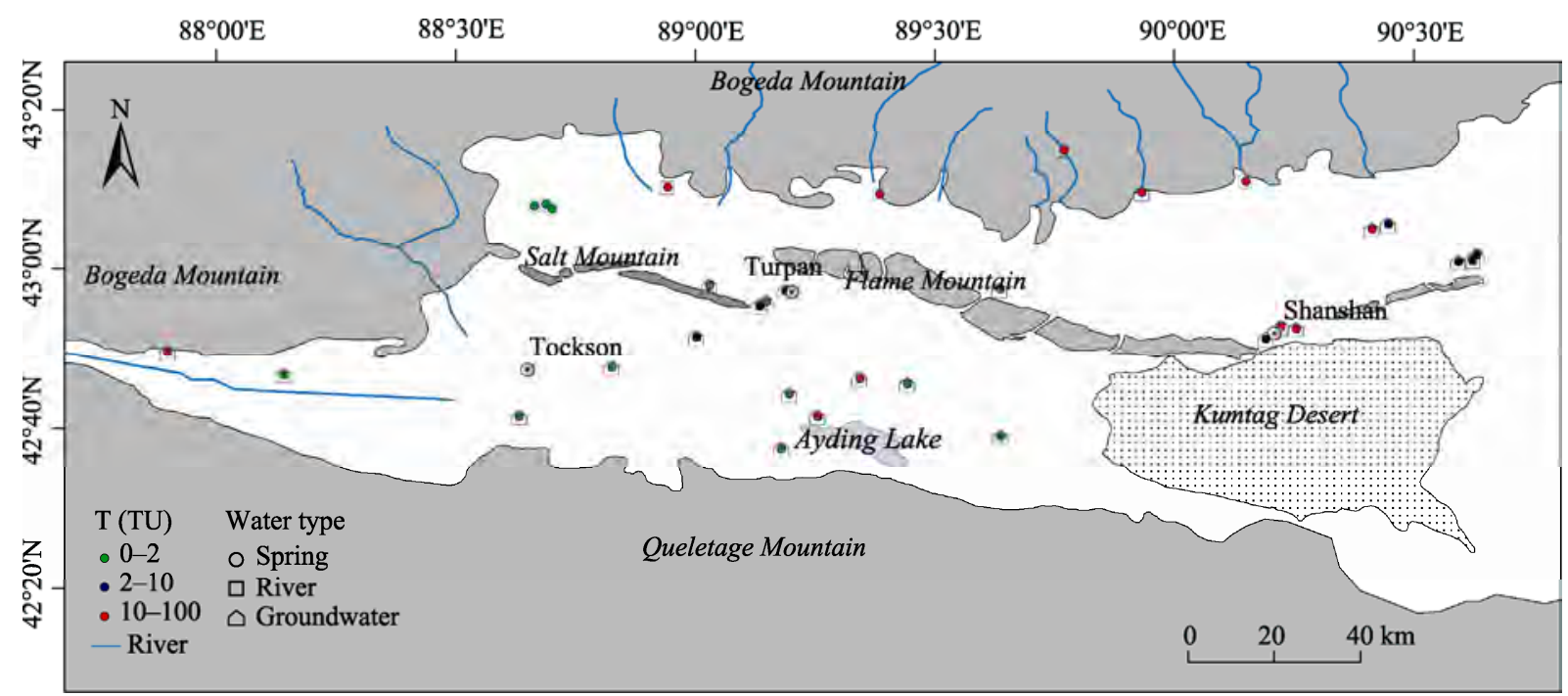

Fig. 11 Distribution of tritium concentration in the Turpan Basin

collected from spring water in the northern sub-basin returned low tritium concentrations. Because the water in the Turpan Basin is recharged from precipitation in the mountain areas (which typically exhibits low tritium concentrations), it can be concluded that these three springs are recharged by groundwater. Conversely, two sampling sites in the southern sub-basin returned high tritium concentrations; both of these samples correspond to water at shallow depths (i.e. 2 and $10 \mathrm{~m}$ ). The above analysis reveals that manmade canal irrigation is the most likely cause of the anomalous tritium concentrations found at these two sites. Examination of the relationship between tritium concentration and groundwater depth also reveals that the groundwater in the Turpan Basin has a critical depth of around $40 \mathrm{~m}$ (Fig. 12): that is, groundwater above $40 \mathrm{~m}$ depth has a high tritium concentration, whereas that below $40 \mathrm{~m}$ depth has a low tritium concentration. Thus, according to the results of tritium analysis, the groundwater in the southern sub-basin can be divided into two groups: a) that which is recharged by groundwater from the northern sub-basin, and b) that which is recharged by artificial irrigation.

\section{Conclusions}

A combination of hydrochemical and environmental isotope analysis has provided new insights into the evolution of regional hydrochemistry within the Turpan Basin. The TDS values for groundwater increase along the flow path from the mountain recharge areas to the discharge areas. In particular, groundwater with high TDS values is found to consist primarily of $\mathrm{Na}-\mathrm{Cl}$ and $\mathrm{Na}-\mathrm{SO}_{4}$ type water, which are located in the central part of the basin. Dissolution of evaporites (particularly halite and gypsum), cation exchange and precipitation of calcium carbonate are found to be the primary contributors to hydrochemistry evolution within the basin. Moreover, the relationship between the dominant ions and TDS indicates that evaporite dissolution likely plays an important role in groundwater salinization. The relationship between $\delta^{18} \mathrm{O}$ vs. $\delta^{2} \mathrm{H}$ shows that groundwater in the Turpan Basin appears to be recharged primarily by precipitation in mountain areas and evaporation in deep groundwater is relatively weak. Analyses of environmental isotope data $\left(\mathrm{Cl}^{-}\right.$vs. $\delta^{18} \mathrm{O}$ and distribution of tritium concentration) and the relationship between TDS vs.

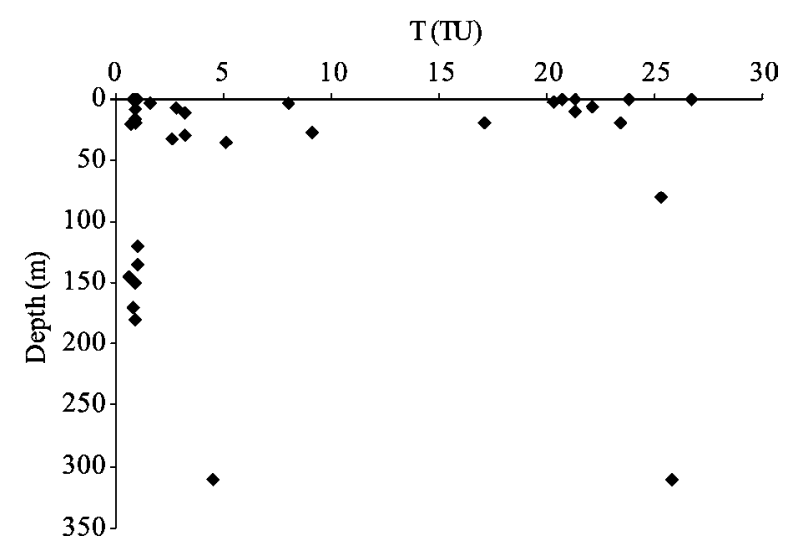

Fig. 12 Scatterplot of tritium (TU) vs. water depth 
groundwater depth suggest that the groundwater in the southern sub-basin can be divided into two groups: (a) that which is recharged by groundwater from the northern sub-basin, and (b) that which is recharged by artificial irrigation. These results will prove useful in decision making related to sustainable water resource utilization in the Turpan Basin and other regions in northwestern China.

\section{Acknowledgements}

This work was funded by Coal Base Groundwater Exploration (Eastern Xinjiang) under the Xinjiang Uygur Autonomous Region 358 Project.

\section{References}

Appelo C A J, Postma D. 2005. Geochemistry, Groundwater and Pollution, $2^{\text {nd }}$ ed. Leiden: A.A. Balkema Publishers.

Carol E, Kruse E, Mas-Pla J. 2009. Hydrochemical and isotopical evidence of ground water salinization processes on the coastal plain of Samborombón Bay, Argentina. Journal of Hydrology, 365(3-4): 335-345.

Chen M X. 1959. The law of the Turpan Basin hydrogeochemistry. Geological Sciences, (6): 185-192.

Craig H. 1961. Standard for reporting concentrations of deuterium and oxygen-18 in natural waters. Science, 133(3467): 1833-1834.

Fass T, Cook P G, Stieglitz T, et al. 2007. Development of saline ground water through transpiration of sea water. Ground Water, 45(6): 703-710.

García M G, Hidalgo M V, Blesa M A. 2001. Geochemistry of groundwater in the alluvial plain of Tucumán province, Argentina. Hydrogeology Journal, 9(6): 597-610.

Ghabayen S M S, Mckee M, Kemblowski M. 2006. Ionic and isotopic ratios for identification of salinity sources and missing data in the Gaza aquifer. Journal of Hydrology, 318(1-4): 360-373.

Guo H M, Wang Y X. 2005. Geochemical characteristics of shallow groundwater in Datong basin, northwestern China. Journal of Geochemical Exploration, 87(3): 109-120.
Halik Abdirahman, Jalalidin Abdusalam, Bian Z F. 2009. Discussion on the water resources and their rational development and utilization in Turpan Basin. System Sciences and Comprehensive Studies in Agriculture, 25(3): 355-360.

Han Y. 2008. Characters of the groundwater flow field and hydrochemistry field in Datong Basin. Geological Survey and Research, 31(2): 138-146.

Howard K W F, Lioyd J W. 1983. Major ion characterization of coastal saline ground waters. Ground Water, 21(4): 429-437.

IAEA. 2001a. Isotope techniques in water resource investigations in arid and semi-arid regions. Iaea-Tecdoc- 1207.

IAEA. 2001b. Isotope based assessment of groundwater renewal in water scarce regions. Iaea-Tecdoc-1246.

Li H, Jiang Z C, Wang Y, et al. 2009. Variation characteristics of stable isotopes in the precipitation of Xinjiang. Research of Soil and Water Conservation, 16(5): 157-161.

Li W P, Zhou H C, Zhou Y X, et al. 1995. The Typical Arid Area of Northwest China Groundwater Flow System. Beijing: Seismological Press.

Qu H L. 1991. Assessment of Groundwater Resources in the Arid and Semiarid Land of China. Beijing: Science Press.

Shi Y F, Zhang X S. 1995. The influence of climate changes on the water resources in arid areas of northwest China. Science in China (Series B), 25(9): 968-977.

Subyani A M. 2004. Use of chloride-mass balance and environmental isotopes for evaluation of groundwater recharge in the alluvial aquifer, Wadi Tharad, western Saudi Arabia. Environmental Geology, 46(6-7): 741-749.

Wang J Y. 2002. Isotope hydrology and water resources plus hydro-environment. Earth Science-Journal of China University of Geosciences, 27(5): 532-533.

Wang Y J, Wu S F. 2003. Environment change over the Aydingkol Lake region in Turpan Basin, Xinjiang. Journal of Glaciology and Geocryology, 25(2): 229-231.

Zhou H F, Zhang J B. 2005. Analysis on the volume of available water resources and its carrying capacity in Xinjiang, China. Arid Land Geography, 28(6): 756-763. 